\title{
INTEGRATIVE RESEARCH AND TRANSDISCIPLINARY KNOWLEDGE PRODUCTION: A REVIEW OF BARRIERS AND BRIDGES
}

\author{
ROBERT AXELSSON \\ School for Forest Management, Faculty of Forest Sciences, Swedish University of \\ Agricultural Sciences, SE-739 21 Skinnskatteberg, Sweden
}

Received: $10^{\text {th }}$ January 2011 , Accepted: $24^{\text {th }}$ February 2011

\begin{abstract}
Contemporary policies about use of natural resources clearly pronounce sustainable development towards the goal sustainability as a focal objective. A key challenge for research is to support improvements and management by evaluation of sustainability policy implementation, i.e. outcomes on the ground and the social process in actual landscapes. However, while a landscape consists of integrated social and ecological subsystems and should thus be treated as a holistic unit or system, most research and postgraduate training is disciplinary. This means that very few researchers are equipped to solve problems or contribute to solutions in the non-academic world. There is thus a need for universities to learn integrative (interdisciplinary and transdisciplinary) research and knowledge production that meets complex challenges related to sustainable development and sustainability issues as for example management and governance of natural resources. In this paper I review the background, concepts and the barriers and bridges to integrative research and knowledge production. As a base for evaluation and development of integrative research projects I propose a normative model for integrative knowledge production processes. This was done through a literature review and a study of an integrative research project. I discuss how transdisciplinary research about landscapes and to solve complex sustainability issues can be designed, viz. (1) there is a need for a common understanding of different types of integrative research, (2) an outspoken aim to develop socially robust knowledge, (3) a model for transdisciplinary collaborative learning processes, and (4) a funding scheme that include academic and non-academic participants and matches the long process of partnership building during the full knowledge production process, from problem identification/definition to an improvement or a management solution.
\end{abstract}

\section{INTRODUCTION}

The need for improved interaction among researchers, policy makers and other relevant stakeholders is emphasized in the European Research Area or "internal market" for research (EC 2007). It is described by the following features: "(1) An adequate flow of competent researchers with high levels of mobility between institutions, disciplines, sectors and countries; (2) World-class research infrastructures, integrated, networked and accessible to research teams from across Europe and the world, notably thanks to new generations of electronic communication infrastructures; (3) Excellent research institutions 
engaged in effective public-private cooperation and partnerships, forming the core of research and innovation 'clusters' including 'virtual research communities', mostly specialised in interdisciplinary areas and attracting a critical mass of human and financial resources; (4) Effective knowledge-sharing notably between public research and industry, as well as with the public at large; (5) Well-coordinated research programmes and priorities, including a significant volume of jointly-programmed public research investment at European level involving common priorities, coordinated implementation and joint evaluation; and (6) A wide opening of the European Research Area to the world with special emphasis on neighbouring countries and a strong commitment to addressing global challenges with Europe's partners". At the university level this is reflected in the Prague and Lisbon declarations of the European University Association (EUA 2009; 2010).

Solutions, innovations and ways to manage and support the sustainable development process in reality are not disciplinary (Farley et al. 2005). A landscape consists of both a geographical area with biophysical, anthropogenic and perceived dimensions, and the social system with its actors and stakeholders from all societal sectors at different administrative levels (e.g., Sauer 1925, Wiens at el. 2007). This is in line with European level policies about rural development, sustainable landscapes, sustainable forest management, water and species habitat (see for example COE 2007, Bryden \& Hart 2004, MCPFE 1998, 2003). Complex policy areas like sustainable development and natural resource management requires a landscape approach. The landscape approach is described as a means to develop sustainable solutions or to manage complex natural resource issues at different levels from local, regional to global and to consider the social and ecological systems as interconnected and interdependent (Noss 1983, Singer 2007, Törnblom 2008, Axelsson 2009). A more comprehensive interpretation of the landscape approach is to see it as a concept with five core features (Axelsson 2009); 1) an area/a landscape, 2) collaboration among multi-level partners representing societal sectors and fields of interest, 3) a commitment to sustainable development and an analytic approach to address sustainability, 4) knowledge production to produce socially robust solutions (Gibbons 1999) and improvements (Walker and Daniels 2001), and 5) sharing of knowledge and experiences, internally and externally. An area or a landscape means a focus on a large area of tens of thousands up to millions of hectares depending on what sustainability issues are at focus. The landscape approach provides a forum were stakeholders meet with an aim to improve the sustainability situation on the ground, not for one or a few instead the focus is on sustainable development in general and to develop partnership synergies (Gilbert 2007), i.e. something better than the least common denominator. This could be done by a stepwise approach guided by the building of respect and understanding among partners, the notion of equity among partners and a common wish to empower all partners to be able to participate in the process (Lickers and Story 1997). When a high level of collaboration has been developed, where all partners are equally important and have developed an understanding and acceptance of each other and each other's perspectives this is defined as a partnership (Svensson 2008, Axelsson 2009).

A large number of arenas, forums and new forms of knowledge production have developed outside the academic world (Gibbons et al. 1994, Axelsson et al. 2008, Axelsson 2009, Angelstam et al. unpublished ms). These new arenas could be seen as responses to the need for socially robust knowledge, i.e. where stakeholders and researchers can learn and produce new knowledge together (Gibbons 1999). There are many terms describing this trend to encourage a change from traditional disciplinary academic to more integrative research, including but not limited to interactive, integrative, action, translational, 
participatory, interdisciplinary, transdisciplinary, and applied research. Gibbons (1994) even claims that due to the gap between academia and practice there is a trend in our society towards more and more knowledge being produced outside academia, i.e. the change from Mode-1 (traditional academic research) to Mode-2 (the new production of knowledge).

In this paper the theoretical background is reviewed, including concepts, the barriers and bridges to integrative research and transdisciplinary knowledge production. As a base for evaluation and development of integrative research projects a normative model for transdisciplinary collaborative processes is proposed. This was done through a literature review of scientific articles, and different landscape concepts, and a study of an integrative research project. I discuss how transdisciplinary research about landscapes and to solve complex sustainability issues could be designed, viz. (1) there is a need for a common understanding of different kinds of integrative research, (2) an outspoken aim to develop socially robust knowledge, (3) a model for integrative, transdisciplinary collaborative learning processes, and (4) a funding scheme that include academic and non-academic participants and matches the long process of partnership building during the full knowledge production process, from problem identification/definition to an improvement or a management solution.

\section{METHODS AND METHODOLOGY}

Three groups of methods were used (Flood and Romm 1997); 1) A literature review that included several scientific fields, such as landscape research, studies about integrative research, new modes of knowledge production, collaborative learning, integrated natural resource management and policy documents, 2) qualitative interviews with stakeholders of an integrative research project, and 3) an analysis of official documents from policies, project evaluations, and project-specific documents. All 25 interviews performed were qualitative open-ended interviews (Kvale 1997, Ryen 2004). The focus was on the organisation, communication and the integrative research process of the project and in general. An interview guide was used but the researchers were given full freedom to express any opinion they had. In addition to the interviews the stakeholder structure and governance of the research project was analysed.

All interviews were transcribed, resulting in more than 1500 pages of text. The analysis of this material used a step-wise approach influenced by grounded theory (Glasser and Strauss 1967). Results were repeatedly scrutinized by iterative comparison with data and other scientific writings (Glasser and Strauss 1969, Alvesson and Sköldberg 1994, Starrin and Svensson 1994). The aim was to reach a point where all the results were grounded in the empiric dataset.

\section{THEORETICAL FRAMEWORKS}

\section{Collaborative learning}

According to Daniels and Walker (2001) collaborative learning is a process-oriented facilitation approach intended for decision making situations characterised by high complexity and conflicts (in motives, power, interest, etc.). Collaborative learning "is a means of designing and implementing a series of events (meetings, field trips, etc.) to promote creative thought, constructive debate, and the effective implementation of 
proposals that the stakeholders generate" (Daniels and Walker 2001). When complemented with peer-review publication in support of producing explicit rather than tacit knowledge (Tress et al. 2006), the collaborative learning approach can be used as a methodology to achieve inclusive socially robust knowledge production processes with many stakeholders (Gibbons 1999).

The collaborative learning approach has three overall theoretical foundations. The first is practice-oriented adult learning theory (e.g., Kolb 1984). Collaboration relies on a notion of the importance of experiential and adaptive learning in multi-stakeholder groups. Innovations are more likely to happen if different perspectives and experiences meet and new ideas develop in such interfaces (Nowotny (1999) called this the hybrid space). However, to be successful, such shared learning is not ad hoc, rather it is based on a structured way of working through complex issues and sometimes conflicting perspectives.

The second foundation is thus conflict management (e.g., Susskind and Cruikshank 1987), inspired from empirical work in a broad range of social sciences. New knowledge might benefit some stakeholders, while they could be potentially negative for others. Furthermore, the actor's perception of the value, relevance and usefulness of new knowledge is strongly intertwined with their interest and existing power relations. With aims to make scientific findings useful in the society science and scientists are forced to approach also conflict management. Although perceiving the produced knowledge as objective per se, its consequences if and when applied are not.

Thirdly, the collaborative learning approach builds on the developments of theories from systems thinking research (e.g., soft systems methodology by Checkland (1989) and critical systems thinking by Flood and Jackson (1991)). The benefit of a systems approach in learning processes is ideally that both the used working approach, as well as the new knowledge produced would be acceptable among stakeholders. Hence, it is more likely to help society manage its real-life problems. The collaborative learning approach aims to both build on established theoretical roots, but at the same time helps shaping and instructing practice.

There are strong arguments for why collaborative learning approaches need to be part of the development of science-based resource management. One reason is that collaborative learning is academically both an interdisciplinary and an eclectic approach (Daniels and Walker 2001). Collaborative learning is thus distinctive "because theoreticians tend to stay in their own pastures", and "very rarely cross the disciplinary fences that divide them". Furthermore, it is a theoretical perspective developed to be useful for practical use and applications. Working with a collaborative learning approach in research takes the challenge of creating new knowledge in the interface between science and society seriously. It does this by accepting the inherent complexity of the issues, while at the same time having the pragmatic ambition of making improvements of the situations at hand.

Daniels and Walker (2001) argue that "ideally, public participation provides a forum where the scientific information and values of the public and the agency can be integrated so that the final decision is viewed as both desirable and feasible by the broadest portions of society". Such collaborative approaches are characterised by shared responsibility and/or authority for the management of both the process and its outcomes (Gardner \& Stern 2002, Weaver \& Jordan 2008, Rauschmayer et al. 2009). However, for this to take place all actors 
must partly change their perspective on knowledge and learning. The focus is not to learn from or to teach; instead it is to collaboratively learn how a problem could be solved and dealt with (e.g., Flood 1999). I argue that this could be a successful approach to handle transdisciplinary research processes and to bridge the knowing-doing gap (Pfeffer and Sutton 1999, Molnar 2009).

\section{Socially robust knowledge}

Socially robust knowledge is acceptable among stakeholders and thus useful knowledge that contributes to the solution of real world problems or influences policy and practice to become more effective in assisting the process of sustainable development. According to Nowotny et al. (2001), the role of science is not only to produce reliable knowledge, but also in what contexts such new knowledge is produced and used. Nowotny (1999) argued that interaction between experts and other actors, for instance the lay public, is one such hybrid space where new knowledge emerges. Gibbons (1999) added to this by stating that "science and society more generally have each invaded the other's domain", resulting in a new contract between science and society at large. This contract has at least two important dimensions. It implies that society takes a more active part in the research process (from agenda setting (e.g., Anon. 2008, FORMAS 2009) to interpretation of results), as well as a need for the scientific community to open up and being willing to listen and appreciate input from society. No more could science be seen as "the fountainhead of all new knowledge" (Gibbons 1999) and being expected to disseminate its discoveries to society in a uni-directional way only.

A "denser communication" between research and society is an imperative to produce more socially robust knowledge (Gibbons 1999). Such knowledge should be characterised by three dimensions. First, it is valid not only inside but also outside the laboratory or the research community. Second, this validity is achieved through involving an extended group of experts, including lay "experts". Finally, "society" has participated in the development of the new knowledge, which may result in it being less likely to be contested than knowledge which is merely "reliable" from a scientific point of view (Gibbons 1999). This also includes the recognition of new knowledge that is being produced through interaction between experts and other societal actors and a successful process. Consequently, socially robust knowledge is reliable both inside and outside the research community, as well as contextualized and adapted to the specific situations in which it is supposed to be applied. As an example the strategy, vision and the statutes of the Swedish research council Mistra for 2009-14 clearly demonstrates its aim to produce socially robust knowledge, in that the knowledge created not only should be of high scientific quality, but also solve real world environmental problems and result in applications (Mistra 1993, 2009). The question is not if socially robust knowledge is worth striving for, but rather how socially robust knowledge could be produced in an integrative/transdisciplinary research programme.

An important aim of socially robust knowledge is to contribute to development, implementation and adaptations (improvements) of policies. Policy development is often described as a cycle, the policy cycle or several nested policy cycles (Mayers and Bass 2004). In short this means that policies are developed, implemented, assessed and adapted over and over again. A policy that has been developed or assessed with a transdisciplinary approach resulting in socially robust knowledge will per definition become more accepted in society. 
It should also be noted here that what is described in this paragraph is an ideal model and something to aim for. In reality people, projects and organisations might use the words integrative, transdisciplinary, and interdisciplinary but never manage to reach higher levels of collaboration, due to for example power inequalities and thus, never will be able to produce socially robust knowledge even if their intentions were good.

\section{Multi-level governance}

In European and North American political theory the term government has been used to refer to the formal institutions of states and their monopoly of power. Characteristics of government have been its capacity to make and enforce decisions (Stoker 1998). Over time society has evolved to become more and more specialised, which has made societal functions and institutions more fragmented. The decision-making power is today divided among several specialised functions, and the government has lost parts of its monopoly. This is a result of a continued development of European and North American democracies, increased availability of information, the deregulation in different societal sectors and emergence of new actors at the national and international arena (Fry 1998, Perritt Jr 1998). Many state administrations are also shrinking in size because societal functions are deregulated and taken over by the private sector. Governments are today affected and influenced by more international agreements and actors and have thus lost parts of their traditional capacity to govern independently. Scholars describe this as a required shift from government to governance. Governance includes multiple actors at multiple levels and is thus often referred to and described as multi-level governance (Bache and Flinders 2004). All the way from local, regional, national, international to global there are today different actors present that make decisions and enforce them. At the same time democracy has developed and made the civil society more active in the decision making process. Consequently, there are today different actors, interest groups and NGOs present on all decision-making levels. This does not mean that government has lost all of its power only that it is more fragmented and that other actors in society have increased their influence on its decisions. Governance could thus be described as decision-making processes and networks (Sundström 2005).

Other scholars describe the duality of governance; from one perspective it refers to government's adaptation to a new context that appeared in the late 20th century while from another perspective it is about a conceptual representation of co-ordination of social systems as the role of government (Pierre 2000). The role of the government is interpreted in two different ways, as the way the government steers the society and as co-ordination, formal and informal collaboration between the public and private sectors (Peters 2000). Research on governance is concentrated on two different main fields; (1) dealing with the states capacity to steer and (2) different modes of co-ordination and self-governance (Rhodes 1994). The governance concept is applicable in more or less all societal sectors and many different contexts (e.g., Foss and Mahnke 2002). Generally it is about the shift from a single or few persons making all decisions in a less complex context to the same person or a small steering group making more informed and influenced decisions to meet the demands in an increasingly complex world (Rhodes 2003).

When discussing issues like integrative research projects, rural development, integrated natural resource management, cultural heritage, biodiversity conservation and the environment in general it is clear that many governance levels affect policies and outcomes in terms of SD on the ground i.e. these are thus examples of multi-level governance. This 
means that the process of SD with many actors at different levels could be seen as a multilevel governance system. In the same way an integrative research project dealing with SD and with the many involved actors at different levels could be seen as a multi-level governance system. To assist SD in multi-level governance systems the development of adaptive governance has been proposed (Folke et al. 2005). Multi-level governance also implies that the management of local to regional SD issues often involves actors from higher levels. Adaptive governance is by scholars viewed as the combination of learning by continuous evaluation (Svensson et al. 2009), reflection (Clark 2002) and the present system of decision making that includes integration of specialist functions and influence from different actors at multiple levels (Folke et al. 2005, Olsson et al. 2007, Armitage et al. 2007). It is a way for the social part of a social- ecological system to develop resilience or capability to resist disturbances by the capacity to re-organising itself when needed (Folke et al. 2005).

In integrative research programmes many different levels of stakeholders can be identified. This is true both internally, i.e. the stakeholders that are directly involved in the knowledge production process, the ones that influences the process, end-users of the research results and externally i.e. all different stakeholders. It is also clear that decision making processes in integrative research processes are good examples of governance processes.

\section{Integrative research}

Research ranges from disciplinary to transdisciplinary (integrative)(Table 1). The different steps in this gradient can solve different kinds of problems. A main aim of integrative research is to support the sustainable development process, and sustainability in landscapes. Integrative research is a general name for research that requires integration among different kinds of researchers and/or stakeholders.

In disciplinary research one or several researchers work within one scientific discipline. There is no integration with other research disciplines or stakeholders. From here the research can get more integrative by the involvement of stakeholders i.e. participatory research or if researchers collaborate by doing research on a common theme, all of them still working within their own research discipline (multidisciplinary research). Interdisciplinary research is to take the integration even further. Here researchers from different disciplines work together on a common theme by bringing in their disciplines, their expertise and together as a well developed collaborative learning process develop a common framework that consists of their respective contributions welded together to something new, an interdisciplinary research framework. This process could also lead to situations where the researchers do not fully agree. In these cases the common research framework will recognise the differences, the researchers will recognise them and there will be additional research questions as a part of the framework. If in an interdisciplinary research process non-academic stakeholders are integrated, this is called transdisciplinary research or transdisciplinary knowledge production. Transdisciplinarity requires an integration of stakeholders in the same way as researchers from different research disciplines are integrated in an interdisciplinary research process (See figure 1 and 2). This calls for research and knowledge production with stakeholders involved (Table 1 and 2, Figure 1 and 2). Any kind of integrative research or knowledge production means the integration of stakeholders (academic and non-academic). In an interdisciplinary research project researchers from different disciplines need to integrate, bring their own disciplinary pieces and mould them together to a framework for the research. For transdisciplinary 
research and knowledge production there is a need to include researchers from different research disciplines, end-users and other stakeholders in the knowledge production process.

Table 1: From disciplinary to integrative research. Terms and their definitions (adapted after Tress et al. 2006). By different disciplines we mean human, social and natural sciences (e.g. Myrdal 2005) as well as different disciplines within the main scientific disciplines.

\begin{tabular}{|c|c|}
\hline Term & Explanation/properties \\
\hline Disciplinary research & $\begin{array}{l}\text {-Only one academic discipline represented } \\
\text {-Disciplinary aim of research project } \\
\text {-No exchange or cooperation with other academic disciplines } \\
\text {-Development of disciplinary knowledge and theory }\end{array}$ \\
\hline $\begin{array}{l}\text { Multidisciplinary } \\
\text { research }\end{array}$ & $\begin{array}{l}\text {-Two or more academic disciplines } \\
\text {-Work from disciplinary perspectives with a common theme } \\
\text {-Loose cooperation between researchers from different } \\
\text { disciplines } \\
\text {-Development of disciplinary knowledge and theory }\end{array}$ \\
\hline Participatory research & $\begin{array}{l}\text {-Academic and non-academic actors } \\
\text {-Exchange of knowledge and research results as information } \\
\text { or dialogue between researchers and non-academic actors } \\
\text {-Disciplinary or multi-disciplinary } \\
\text {-Development of disciplinary theories and knowledge }\end{array}$ \\
\hline $\begin{array}{l}\text { Interdisciplinary } \\
\text { research }\end{array}$ & $\begin{array}{l}\text {-Two or more integrated academic disciplines } \\
\text {-The development of a common scientific framework and } \\
\text { goal among participants from different academic disciplines } \\
\text { and for the whole research project } \\
\text {-Delopment of integrated knowledge and theory }\end{array}$ \\
\hline $\begin{array}{l}\text { Transdisciplinary } \\
\text { research }\end{array}$ & $\begin{array}{l}\text {-Multiple academic and non-academic actors } \\
\text {-Development of a common framework and goal among all } \\
\text { actors } \\
\text {-Integration of academic and non-academic actors } \\
\text {-Development of integrated knowledge and theory }\end{array}$ \\
\hline $\begin{array}{l}\text { Participatory } \\
\text { knowledge production }\end{array}$ & $\begin{array}{l}\text {-Academic and non-academic actors } \\
\text {-Exchange of knowledge and research results as information } \\
\text { or dialogue between researchers and non-academic actors } \\
\text {-Disciplinary or multi-disciplinary } \\
\text {-Non scientific or scientific aim to solve real world problems } \\
\text { and to develop disciplinary theory }\end{array}$ \\
\hline $\begin{array}{l}\text { Transdisciplinary } \\
\text { knowledge production }\end{array}$ & $\begin{array}{l}\text {-Multiple academic and non-academic actors } \\
\text {-Development of a common framework and goal among all } \\
\text { actors } \\
\text {-Integration of academic and non-academic actors } \\
\text {-Non-scientific or scientific aim to solve real world problems } \\
\text { and to develop transdisciplinary theory }\end{array}$ \\
\hline
\end{tabular}


This means that transdisciplinary research is a complex process were all knowledge production stakeholders will bring in their expertise and through a collaborative learning process (Daniels and Walker 2001, Cheng and Fiero 2005) will develop a common framework for the research. In addition there is often a need for some participants to contribute in the process with their disciplinary expertise only. While the main knowledge production process requires most of the researchers to work with an inter- or transdisciplinary perspective to be able to facilitate the production of socially robust knowledge (Gibbons 1999, Nowotny 1999, 2001).

Table 2: A normative model for transdisciplinary knowledge production, based on the works of several scholars .

\begin{tabular}{ll}
\hline Step & Activities \\
\hline 1 & $\begin{array}{l}\text { Assessment of the context and the potential for collaboration, identification of } \\
\text { gaps. }\end{array}$
\end{tabular}

2 To plan and work with the prerequisites for a successful transdisciplinary research process, identification of actors.

3 Integration and partnership building, among academic actors, non-academic actors and integration of the two groups, learn collaboration, start small and develop the skills step by step.

4 Development a common framework for collaboration. This includes researchers and end-users.

$5 \quad$ Planning for the implementation of the project.

6 Implementation and facilitation of the project.

7 Continuous evaluation, reflection and adaptation. This includes researchers and end-users.

\section{The development of a normative model for transdisciplinary knowledge production}

A normative or "ideal model" was developed and used as a benchmark for comparison with the performance of the research project. This model was based on the operational strategy for the studied research programme and the research council that funded the project, the statutes of some Swedish research councils, a literature review and empirical data from the research project. For the model works by different scholars on definitions of integrative and collaborative approaches to knowledge production were used. Note that the modifications to the frameworks (Table 1) is not an attempt to increase the diversity of different kinds of research approaches, instead it should be seen as a variable axis and scale that could be used to assess the level of integration and outcome of a given research programme or activity. The proposed model is by no means the only way to run an integrative research project. Instead it is a way to benchmark an integrative research project and to improve the understanding of integrative research as a collaborative learning process (Daniels and Walker 2001). It could of cause also be used as inspiration and a starting point for integrative research projects. 
Additional inspiration for the normative model comes also from ideas on processes to establish good governance for management of natural resources, the collaborative learning approach (Daniels and Walker 2001), ideas on socially robust knowledge (Gibbons 1999, Nowotny 1999, 2001), and existing frameworks for inter- and transdisciplinary research projects as well as for the evaluation of such projects (See coming paragraph on barriers and bridges). The ideas on a collaborative transdisciplinary research process were developed from and inspired by the works of Daniels and Walker (2001), Barbour et al. (2004:53), Borrini-Feyerabend et al. (2004:139), Blagovidov et al. (2006), Naveh (2007) and others. Those researchers describe processes for the development of governance systems for conflict situations and landscape approaches (e.g., Dudley et al. 2006, Singer 2007) such as Model Forest (IMFN 2008), Biosphere Reserve (UNESCO 1996, 2002) and EU Leader (Bryden and Hart 2004), the collaborative learning approach (Daniels and Walker 2001) and research on integrative research processes (Fry 2001, Svensson et al. 2002, Stokols 2003, Tress et al. 2006, Agaard Nielsen and Svensson 2006, Johannisson et al. 2008).

Daniels and Walker (2001) describe five distinct phases in a collaborative learning process; 1) Assessment - where an evaluation of the context and the potential for collaboration takes place, 2) Training - where stakeholders build an appreciation for collaboration and learn some specific techniques of collaborative learning, 3) Design development of a context-specific strategy for involving stakeholders in a meaningful process, 4) Implementation/facilitation - to conduct project activities and decision making, 5) Evaluation - data gathering and reflection to learn from participating stakeholders with the aim to assess different approaches and their result to assist project adaptation and to learn for future projects.

Similarly, Tress et al. (2006) emphasized five steps in order to achieve a successful integrative interdisciplinary and transdisciplinary processes. They emphasized the importance of 1) preparing an integration implementation plan that identifies the aim of integration, the necessary steps to realize integration of the expected integrative outputs and a clear time schedule, 2) planning for smaller rather than larger projects, 3) allowing additional time to develop a common language, a common aim and common outputs, 4) arranging regular meetings and events to help project participants get to know one another, trust each other and develop a common understanding of the research process, 5) planning realistic outputs that can be delivered on time and avoid setting expectations too high in order to please funding agencies and stakeholders (Tress et al. 2006).

\section{RESULTS}

\section{Barriers and bridges in integrative research and knowledge production}

Already in 1944 Brozek and Keys proposed that researchers should develop; (1) facilities for getting acquainted with the problems and methods of the neighbor fields, (2) the 'science of science' which would provide necessary philosophical perspectives, and (3) social skills required for a stimulating and efficient scientific cooperation (Brozek \& Keys 1944). In addition they conclude that "A team of research workers representing various disciplines can be welded into a fully integrated unit only on the basis of extensive experience of working and thinking together.". These are still today very valid proposals and conclusions. 
In this paragraph some of the barriers and bridges that different scholars have identified while assessing integrative research projects and processes will be presented. The definition of what different words mean is by many pointed out as a barrier (Thompson Klein 2004, Lawrence 2004, Madni 2007). Here one could also include the vast amount of different terms and terminology that are used for integrative research (Axelsson 2009). The in this study proposed terminology disciplinary, multidisciplinary, participatory, interdisciplinary and transdisciplinary research, and participatory and transdisciplinary knowledge production (Table 1, Tress et al. 2006, Axelsson 2009) is a synthesis of many proposed definitions, compared to some simplified and thus hopefully easier to understand. The first word describes the participants (disciplinary, multidisciplinary, participatory, interdisciplinary, transdisciplinary) and the second the output of the research effort, research as an academic output and knowledge production describing new knowledge/solutions that is needed to improve, manage or solve issues in the society (Axelsson 2009). In line with Gibbons (1993) this implies a responsibility to both produce this knowledge and to bring the knowledge to stakeholders that need it and will be able to use it. The main deviation in this definition compared to some of the more science philosophical definitions lies in the differences between interdisciplinary and transdisciplinary research (these scholars often do not differ between research and knowledge production). They describe the differences between interdisciplinary and transdisciplinary research as if; interdisciplinary- researchers still have their own base in their respective disciplines while creating something new together, transdisciplinaryresearchers goes a step further and beyond their disciplines, beyond interdisciplinarity, leaving their disciplines and becoming transdisciplinary researchers (de Freitas et al. 1994, Nicolescu 2002, Jakobsen 2002, Neuhauser et al. 2007). To me this is not a contradiction; instead it is another perspective of integrative research. The only problem is that the same words are used. I propose the use of interdisciplinary and transdisciplinary integration of the research process to describe this perspective, and for scholars to always be very careful in describing what we mean when using these terms. Another perspective is the discussion of transdisciplinarity and true transdisciplinarity where participants mirrors all the differences in the real world like nationality, ethnicity, culture, in addition to many other properties that could be used to invite stakeholders to a transdisciplinary knowledge production process (Ertas 2000). Many scholars also point out the need to develop specific integrative theories and to do research about integrative research (Brozek \& Keys 1944, Fry 2001, King et al. 2002, Wiesman et al. 2008).

Scholars point out the relevance of integrative research and knowledge production, universities are disciplinary while reality is not (de Freitas et al. 1994, Steffen et al. 2004, Farley et al. 2005, Wiesman et al. 2008). As it seems the policy level have identified the problem but universities have not yet managed to meet it (Wijkman 1999, EUA 2009, 2010, Vasbinder et al. 2007). Some describe it as a large and still growing demand for integrative research and academia's lacking capacity to engage in it (Green 1997). Gray (2008) stresses the mismatches between rewards for disciplinary competence over innovation, and institutional disincentives that often impede or prevent transdisciplinary research and knowledge production projects from being successful. Others describe the "scientist fake" phenomenon, were researchers use the terminology of integrative research, participate in projects while still doing business as usual (Brewer 1999b). They are educated as disciplinary researchers and that is what they know and do well. Even if we as researchers are curious to learn new things, to understand new phenomena and solve scientific problems we are most often not able to see and understand the limits of our own educations 
or willing to re-learn if our belief systems are challenged. Then it is often easier to hide and continue to work as we once learned as students (Garkovich 1982, Brewer 1998b). This leads us to education, university education at all levels are most often disciplinary. Universities have up until now, to a large extent failed to meet the societal need for integrated education (Garkovich 1982, Fry 2001, Hammer and Söderqvist 2001) even if there are some exceptions (see for example Bawden 1993, Hammer and Söderqvist 2001, Miller et al. 2008). The adaptation of universities to meet and collaborate with the nonacademic world is a major challenge since a clear majority of researchers and teachers once were educated at disciplinary education programmes.

The gap in education in relation to national and international policies also points at the problem with the university- policy interface (Wijkman 1999, Brewer \& Lövgren 1999, EUA 2009, 2010). In the same way as universities to be successful in an integrative endeavour need to improve integration with stakeholders there is a specific need to integrate with policy and policy-making processes. This integration would influence both education and research. It is not easy and universities will not be able and should not react on each change in policies. Still it is today obvious that universities need to develop together with our societies to match the needs of them. As Stokols (1998) claims there is a need to train a new generation of transdisciplinary scientists, trained to be strong scientists, most often with their roots in a primary research discipline but able to understand and use theories and methods that integrate disciplinary perspectives. This is an interesting ambition level that could be transferred to all higher educations. Learn your discipline but improve the connections to and understanding of the matrix i.e. the surrounding. Include many different perspectives instead of one true disciplinary truth in any educational programme. This will certainly help in creating reflective practitioners and researchers (Schön 1982, Clark 2002) and multi perspective thinking (McGregor 2004).

There is also a language barrier between different research disciplines (Ertas 2000, King et al 2002, Klein 2004, Neuhauser 2007). The same words are used describing different phenomena. Some researchers discuss the development of an "Esperanto" for researchers (King et al. 2002) or language harmonisation (Pereira and Funtowicz 2006). This will be more and more evident with the increasing body of knowledge produced by researchers world-wide. There will definitely be a need for more research about research, on the interfaces between different research disciplines and tools developed to search for, filter, translate and quality control research results between different disciplines. We have the last decades seen an immense development in data and research result availability now there is a need to develop tools that can assist use of these data, knowledge management and knowledge integration (McGregor 2004). Technology will most probably solve many of these problems, if there is a market for the solutions, still quality control will be a major issue. In this paragraph language and communication barriers between different research disciplines have been described, the language barriers are also evident between academics, non-academics and different non-academic groups (Stokols 2003, Neuhauser 2007, Hirsch Hadorn 2008). This calls for the need of communicators, facilitators and brokers in integrative research and knowledge production (Ertas 2000, Morse et al. 2007, Wiesman et al. 2008, Gray 2008, Axelsson 2009).

This leads us to the barrier of integration and differences in how different scientific and non-scientific actors perceive the world. How to build a team from stakeholders that have individual interests and stakes? A team that as a group could develop large and complex 
knowledge production processes, that could solve large problems even if a majority of stakeholders are active and with their direct interests at the local level only. What would be the driving force for a stakeholder to engage in an integrative knowledge production process? Who are the relevant stakeholders? In a world were individualism has developed into something preferred, both in the academic world and in the society at large there is a need to collaborate, to work together to develop solutions that would benefit many. To handle the barrier of integration there is a need for; champions- persons that fight for a cause larger then themselves, communicators- persons that assist participating stakeholders to communicate, brokers- persons that are capable of bridging different stakeholder groups and facilitators- persons with skills to handle and facilitate the complex process of an integrative knowledge production process (Olsson et al. 2004, Hahn et al. 2006, Axelsson 2009). An important property that is needed is humbleness towards other stakeholders, their ideas and their proposals. Lickers and Story (1997), connecting to traditional knowledge in a natural resource management context describe this as the development of respect, equity and empowerment among stakeholders. Axelsson (2009) talks about developing collaboration to higher levels were a partnership is the aim and highest level of collaboration. Others talk about recursiveness and calls for a participatory process from problem identification to solution (McGregor 2004). In reality this might mean that one or a few actors initialize the process, invite more and more stakeholders and are open to any adaptation and re-iteration of the process that is proposed by participants (Brewer 1999a).

This leads us to who we are and what we want. In an integrative knowledge production process we acknowledge participant with many differences. Even as researchers we would need to reflect on whom we are and what we want. An interesting approach and tool is the "Transdisciplinary self orientation tool" proposed by McGregor (2004). Transdisciplinarity could be seen as more than a way of producing new knowledge, the ethic of being open minded while theorizing from a broad context oriented approach, including different disciplinary and non-academic views (Gibbons 1994, Stokols 1998, Ertas 2000) and transdisciplinary thinking (Albrecht et al. 1998).

Who are the stakeholders? Anyone that is interested and willing to contribute is an easy answer. But how do we deal with this practically? Who should finance the project, stakeholder participation etc.? A true transdisciplinary knowledge production process is dynamic (Brewer 1999a). It will start with a few champions and invite stakeholders that are representative in relation to the research issues. Along the process different gaps in knowledge might be detected and filled. This might call for new participants, and new stakeholders. This will take time and it will be costly. Efficiency seen as the production of scientific articles per time unit only will be a poor way to measure the success of integrative research projects. In fact even the project itself might be problematic, or to create a complex integrative research process and get funding for all needed parts in one project from one funding agency. Instead a focus on the process, the collaboration, collaborative learning and partnership development and to have a common aim or will to develop a solution could be an alternative for complex tasks. Funding will then have to be handled by arranging what is needed from different sources for different stakeholders and different parts of the process (see Figure 3 and Axelsson 2009 for a proposed funding model for integrative research). All interested stakeholders are capable of contributions in an integrative research process. There will often be a need to see the work as a collaborative learning process, to learn together as a group and to bring wider learning to the group by including each other's perspectives as a part of each stakeholders knowledge base (Daniels 
and Walker 2001, Wiesman et al 2008). The ultimate aim would be to reach a space, the innovative, creative, hybrid space (Nowotny 1999, 2001) or an intellectual outerspace (Lattanzi 1998) were the stakeholder's experience, knowledge and different perspectives leads to new knowledge or new interpretations (McGregor 2004). In reality disagreement is more likely. Integrative research processes often ends in squabbles among researchers from different disciplines and academic and non-academic actors about the validity of each other's conceptual frameworks, and the discrepancy between what is good science and needs of end-users and other stakeholders (Gray 2008, Axelsson 2009).

\section{Fig 3: The different phases of a transdisciplinary knowledge production project.}

The heights of the boxes indicate the relative need for funding during different phases of the project. In contrast to this sigmoid progression of need for funding most project have a rectangular progression over time (adapted after Axelsson 2009).

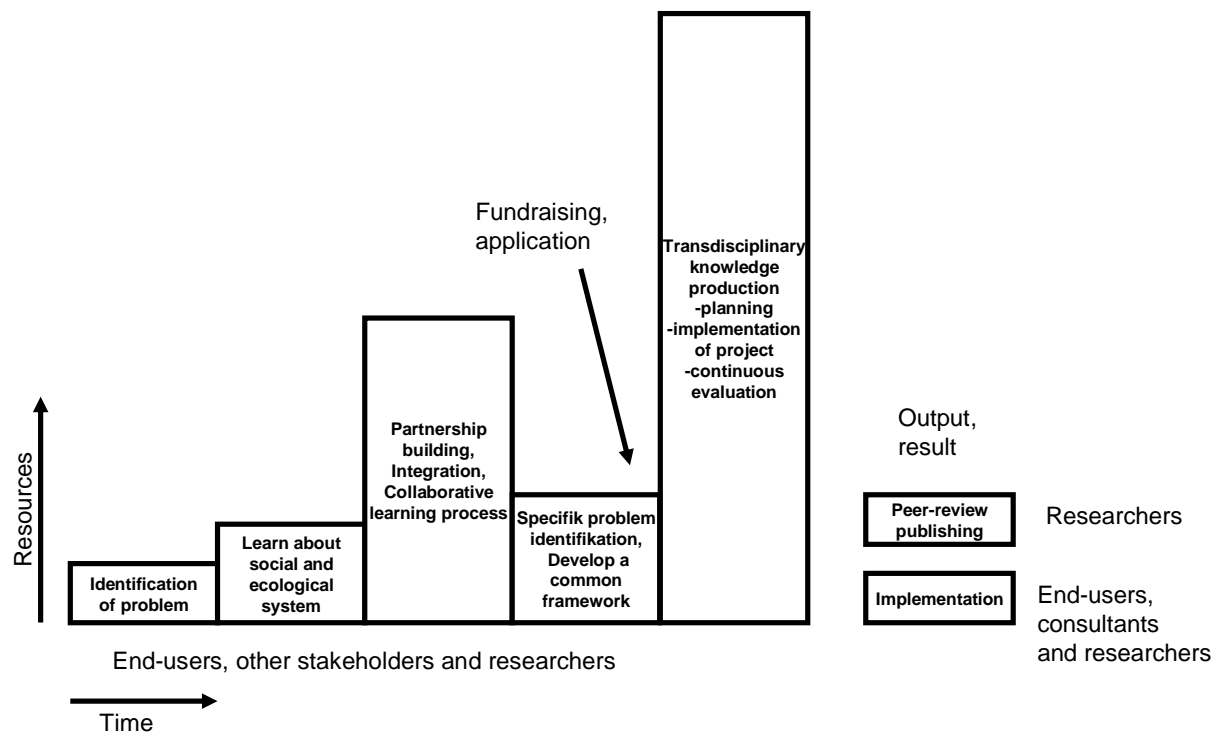

A major problem is that integrative research, although undisputably needed in the society is not fully accepted and a part of universities yet (Wijkman 1999, Gray 2008, Wiesman et al. 2008). This is due to academic traditions, the merit system and a lack of integrative theory (Fry 2001). The present merit system considers academic quality as number of published scientific papers and their academic impact factor (Garfield 2005). For social robustness and usefulness of the research results there are no systems in operation yet and they will be much harder to develop and use. At the Swedish University of Agricultural Science the quality and impact of research was evaluated recently. The evaluation included an external assessment, a bibliometrical analysis and a self evaluation and it took almost 18 months (von Bothmer et al. 2009). A major problem for integrative research groups was to find a proper group for the assessment. This problem brings us to the problem to evaluate the quality of integrative research (Fry 2001, Gray 2008). In the same way as integrative research is not fully accepted at our universities the same goes for the society. End-users, 
funders, and non-academic stakeholders often do not accept the role of being partners in the knowledge production process (Gray 2008, Axelsson 2009). Transdisciplinary research for sustainability deals with large and complex issues and thus requires large groups of stakeholders. To develop transdisciplinary thinking, handle the complexity itself, develop a common framework and to merge stakeholder views are some barriers correlated to integration (Albrecht et al 1998). Integration is often easier for smaller projects (Tress et al. 2006, Gray 2008).

\section{A normative model for transdisciplinary knowledge production}

The proposed model has 7 steps (Table 2). These are;

(1) Assessment of the context and the potential for collaboration, identification of gapsHere the project champions, a few stakeholders representing both research and other research theme stakeholders together analyse the situation, make a first assessment of the research context and a rough identification of sustainability issues, research area, questions and knowledge gaps related to them. Next the potential for collaboration is analysed (Daniels and Walker 2001), which includes a rough mapping of relevant research theme stakeholders (Elbakidze et al. 2009). The final step would be to together in the group of champions decide whether it is worthwhile or not to try to develop a research project. It is at this time also necessary to secure funding for the continued process of developing a transdisciplinary knowledge production project,

(2) To plan and work with the prerequisites for a successful transdisciplinary research process, identification of actors- At this time some initial funding need to be secured. A rough plan for the remaining steps of the research process will be produced. This plan is however open for changes, adaptations, and improvements according to the outcome of the continued process. A multi-level map of relevant actors is developed. This should initially be a very inclusive process. Academic actors, end-users and other stakeholders are identified and contacted. This step also includes an assessment of the stakeholder's interest, capacity to contribute in the research project as well as the need for further funding,

(3) Integration and partnership building, among academic actors, non-academic actors and integration of the two groups, learn collaboration, start small and develop the skills step by step- This is maybe the most crucial step of the knowledge production project. Here the project team is built by academic and non-academic actors. Depending on the number of project theme stakeholders and the size of the planned project different approaches could be used. It should also be noted that it is easier to develop fruitful transdisciplinary knowledge production processes with limited number of researchers, end-users and other stakeholders (Tress et al. 2006). In the case of fewer (up to 20) project stakeholders it should be possible to work with the full group. In cases with more project stakeholders a strategy with multilevel and potentially multi-sectoral partnerships is proposed. The end result would be a project or preferably a theme partnership consisting of smaller partnerships. This would be the case for very complex and overarching research issues that deals with solutions for how to steer our society towards a more sustainable state (Lee 1993). Integration and partnership building or to develop a high level of collaboration among stakeholders include steps like; learn to know each other, learn to know each other professionally, build respect and knowledge about each other's professions, interests and perspectives, and an understanding among the stakeholders of how much manoeuvrability there is within each stakeholders frame. Important parts are equity among partners and empowerment of stakeholders to allow them to participate in a collaborative learning process (Lickers \& Story 1997). This is 
equivalent to social learning, to bring the whole group further in the transdisciplinary knowledge production process, a collaborative learning process and to not leave anyone behind (Daniels \& Walker 2001, Leeuwis \& Pyburn 2002, Keen et al. 2005, Wals 2009),

(4) Development a common framework among all research project stakeholders- This step is also a good example of a collaborative learning process (Daniels and Walker 2001) where project stakeholders change, redesign, improve or adapt the plan from step one. This might result in one or several problem definitions and knowledge gaps that need to be accepted by all stakeholders and included in the research framework for the project. This does not mean that there need to be a consensus on all research issues only that all stakeholders respect each other and acknowledge that there are differences. For comparison with a traditional disciplinary or multidisciplinary research project, these 4 first steps are replaced by the writing of a proposal. Naturally parts or fragments of these four first steps are commonly included also in traditional research projects.

(5) Planning for the implementation of the project- At this stage there is a common agreement on the frame of the research project among stakeholders. The plan for the research project is produced in the same way as in previous steps, as a collaborative process,

(6) Implementation and facilitation of the project- Under step 6 the knowledge production is intensified and most parts of it are produced here. This could include many different kinds of research (See figure 1 and 2). The overall knowledge production process is however a collaborative learning process including all or relevant stakeholders. Still researchers have a key role to record, analyse, write about the research results, and to care for the quality assurance by publishing the results,

Fig. 1: The core feature of transdisciplinary knowledge production.

The word "pieces" in the box in the figure includes stakeholder experience and knowledge, existing scientific knowledge, and new knowledge, both disciplinary and integrative.

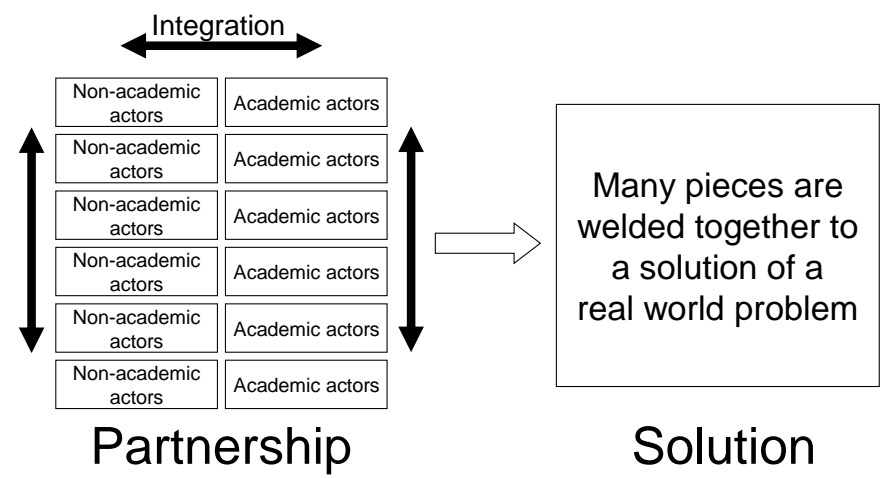


Fig. 2: A model for integrative research (Tress et al. 2006).

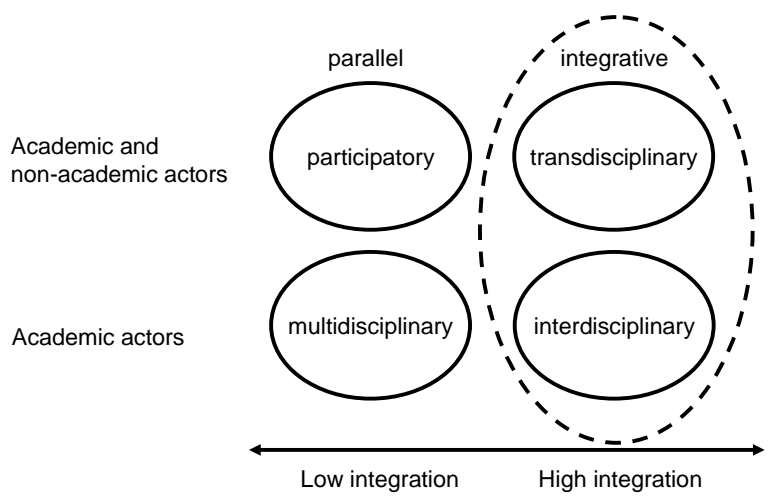

(7) Continuous evaluation, reflection and adaptation done by researchers, end-users and other stakeholders- To secure a successful collaborative learning process there is a need to use the principle of learning through continuous evaluation (Svensson 2009). This is not like being controlled by an external auditor. Instead it is a process were project stakeholders individually, together and sometimes with external support, reflects on the knowledge production process. Communication is a key word here, stakeholders need to evaluate if the process is contributing according to their interests and to what degree the creation of a transdisciplinary knowledge production process have been successful. A collaborative learning process means that as stakeholders learn from each other, there might even be a need to question some or all initial assumptions that the project was built on.

The proposed steps in the model should not be seen as isolated phases, instead they overlap, and several of them will work in parallel, or it might be a need to go back to a previous step in a fruitful transdisciplinary knowledge production process. It should also be noted that for a successful research process there might be a need for some researchers that are working within their disciplines and contributing to the transdisciplinary knowledge production process by the production of disciplinary knowledge that is needed and fits in the bigger process.

After the seven steps there is still work to do. The new knowledge will now be used. In some cases this might be easy, there are pieces of knowledge, new approaches, tools and even new products that could be picked up or brought into management by practitioners. In many cases there is however a need to adapt the new knowledge before it is useful. This could be done by practitioners alone or in collaboration with consultants, researchers and other stakeholders. For researchers the after-work includes publication of the results (even if some results were published during the project). This is a continuation of the research process were also new knowledge could surface as more and more of the research project publications are published. Especially general synthesis of the research process might occur here. Even during this after-project phase continued stakeholder collaboration will be very beneficial. 
Seven steps, a lot of different issues to consider, collaboration among stakeholder and more. It is obvious that transdisciplinary knowledge production processes require longer time frames (Se figure 3 ) than traditional disciplinary research projects.

\section{DISCUSSION}

\section{The studied transdisciplinary research project and further studies}

This study had the aim to review barriers and bridges in integrative research and to propose a process oriented normative model for integrative knowledge production processes. In coming studies the author together with colleagues will assess the studied integrative research project using a comparative approach and the normative model. This first study still shows that many of the bridges and barriers identified by different scholars could be found in the studied research project as well. The main problem in this project was the leadership and its failure in understanding an integrative knowledge production project as a process that needed facilitation (Axelsson 2009), a collaborative leadership (Gray 2008) and a collaborative learning approach (Daniels \& Walker 2001). In addition the understanding of integrative research models varied a lot among the researchers and other stakeholders but was in general poor. Some of the researchers had a background from projects were they did research specified by the end-user, i.e. closer to consulting. Others had never been close to developing solutions or tools to assist end-users directly. The main group however, had some experience and an interest to learn how to develop a transdisciplinary research processes to produce for the society useful knowledge. When research is transdisciplinary it moves closer to non-academic knowledge production and consulting. Many researchers feel threatened when their work comes close to the border between applied research and consulting. Properties such as demand-driven, professional practice, problem-solution, dependence, acceptance/agreement on problems could be used to describe consultancy and such expressions are also to some extent applicable for applied integrative knowledge production processes. The border between transdisciplinary knowledge production and consulting thus needs to be further explored. Consulting is rarely published in scientific journals and the results often are owned by the customer, and thus the consultant (if a researcher) often cannot use the results after their consulting work ends. Consulting that produces new knowledge but that is not spread or published is equivalent with the concept of tacit knowledge (Nonaka and Konno 1998). By contrast research is more or less by definition published in peer reviewed journals or books. There are also researchers that produce different kinds of reports, so called grey literature. One diagnostic feature of research is that it aims at contributing to the global scientific body of knowledge by peer-review publishing, i.e. creating explicit knowledge (Nonaka and Konno 1998). However, this is not a unique property since also results from consultancy work performed by researchers sometimes is published in scientific journals. A key property of consultancy work is that it is the buyer that defines the problem, and sometimes even the solution. By contrast, in integrative knowledge production the problem is defined as a collaborative learning process among academic and non-academic stakeholders.

\section{Gap between the societal needs and researchers capabilities}

There is a wide spread agreement on the need for transdisciplinary research processes to handle complex sustainability issues (de Freitas et al. 1994, Wijkman 1999, Farley et al. 2005, Wiesman et al. 2008, EUA 2009, 2010, Vasbinder et al. 2007). This relates to large and important questions for the human society (Greene 1997, Steffen et al. 2004). A main 
problem is that there seem to be no vision or plan on how to transform this agreement to action on the ground i.e. researchers or others that can handle transdisciplinary knowledge production processes. Within the academic world the dominant view is that a researcher should be strong in his discipline, and only from that position it is possible to develop into an integrative researcher. More or less all today active researchers have a disciplinary or in best case a multidisciplinary research education. There is no or little only reward to researchers that are interested in integrative knowledge production. What counts in the academic world are the number of scientific publications and the impact factor of the journals where they are published. A scientific journal's impact factor is a measure of how many scientific references that are made to the articles that was published during a year. The impact factor of a scientific journal is frequently used as a proxy of the relative importance of a journal in its research field (ISI 1994, Garfield 2005). This is clearly an academic impact factor, a measure of the academic value, how well-known the researcher is or colleague's appreciation of the research. In relation to the needed further development of integrative research and knowledge production there is clearly a need for a non-academic impact factor as well.

Research education is most often disciplinary and thus researchers often are not aware of the differences between different modes of knowledge production and their implications to the research process (Axelsson 2009, EUA 2009). In reality this means that integrative research processes are hard to manage for disciplinary researchers and thus, often fails (Mobjörk 2004, Tress et al. 2006, Gray 2008). Hence, the efforts to adapt the works of Tress et al. (2006) and others to cover different kinds of research, non-academic knowledge production and different integrative knowledge production processes. To facilitate discussion and improve the understanding of the different modes of knowledge production and their requirements they were sorted and characterized (Table 1). As has been discussed above, integrative research and knowledge production requires integration. The highest level of integration could be called a partnership (Svensson 2008). A partnership is a group of equal stakeholders that have learned about each other, that respect each other and where potentially weaker stakeholders has been empowered to enable them to participate in the process (Lickers and Story 1997, Pollock 2004). This means that integrative research projects will need longer time and include phases that are uncommon and hard to handle for traditional researchers (Borrini-Feyerabend 2004, Tress et al 2006, Axelsson 2009).

In addition there is a need to educate integrative researchers, and to include knowledge about many different kinds of research, including integrative in the curricula of all higher and research education. This need has been noted at the political level and brought up as a priority by the European University Association (EUA 2009, 2010). Everyone could learn what integrative research is what it means to be a part of an integrative research process. To lead an integrative research process however, requires in addition a number of personal features like seniority, experience, a transdisciplinary vision, communication and facilitation skills, and the capacity to collaborate with many stakeholders from different academic and non-academic fields (collaborative leadership, see Gray 2008). The larger the transdisciplinary knowledge production process is the more demand it will put on its leader. There is a trend in Europe for larger and more integrative research funding today. To answer this there is a need to include in addition some leadership training in research education with the aim to both teach the students and to identify potential future research leaders. 


\section{Challenges of transdisciplinary research}

For a large and complex transdisciplinary research project there is a need to understand knowledge production as a process that needs to be actively facilitated. Facilitation means that there is a need to assist communication and to make sure everyone is listened to and taken into account. This requires good communication skills and either seniority in terms of long past practical experience in research programme management, or an independent well equipped facilitator.

It would also be beneficial with a comprehensive introduction to integrative research where the project management/facilitator, the researchers, the end-users, other stakeholders, and an invited expert team learn about integrative knowledge production from the participants' own previous experiences. Most participants have some past experience, and it should be acknowledged that there seem to be very few experts in the field of transdisciplinary knowledge production at most universities and elsewhere. Still gaps need to be identified and bridged by a carefully facilitated collaborative learning process that would in addition be the beginning of the integrative process. In the evaluated integrative research programme it was clear that the end-users did not see themselves as a part of the knowledge production. When large government bodies fund research it might even be that a need for research is recognized in a specific department. The department sends a wish for a research project to the government organisation's procurement office. This office produces a call for a research project more or less independently. The strict procurement regulations might be a problem and cause the procured research to be something else than what was needed, and was identified as a collaborative learning process.

The largest challenge for the assessed research project to implement the idea of integrative research was the lack of understanding and appreciation for transdisciplinary research among its management and end-users as well as in the society and at most of our universities' departments. It can thus be viewed as a conflict between the paradigms of traditional disciplinary research and transdisciplinary knowledge production.

Transdisciplinary knowledge production also requires a matching end-user project for the integration of the end-users, and end-users and researchers. In a small project researchers and end-users could be integrated simultaneously. However, in a complex large research programme with many actors, there is a need for a step-wise approach. In the assessed research project the lack of a unified counterpart became even more evident since the board for the whole research programme was not well integrated among themselves or with the researchers and did thus not act as a unified body.

The style of leadership needed for integrative research is characterised by openness, transparency and with a strong emphasize on collaborative learning, team-building and networking (Daniels and Walker 2001, Svensson et al. 2002, Tress et al. 2006). A more traditional-conservative command and control oriented style will not work at all. Tools to improve communication, to give participants equal opportunities to speak could be important (See Open Space as an example, Harrison 1997). One option might also be to meet the end-users in their home territory, i.e. consistent with a case study approach, being either thematic or geographical. 


\section{CONCLUSIONS}

Realising the visions of policy-makers, research councils and other donors to support transdisciplinary knowledge production processes requires knowledge and understanding of these processes. Much time and collaborative learning processes that with a stepwise approach, building on and continuing from previous experiences are needed to learn how to handle them. Introduction, integration and facilitation are three key words. All participants, be it end-users or researchers, need a comprehensive introduction to integrative knowledge production. A key task is integration; all participants must feel needed and have the same opportunities to influence while at the same time differences between the roles of researchers, end-users and other stakeholders must be understood. End-users must reevaluate their role as customers only and receivers of the research results since a much more active participation is a requirement for transdisciplinary knowledge production. It is also important that the right individuals from the end-user organisations are involved i.e. the busy project managers from different kinds of development projects instead of only the environmental officer. All this will not happen by itself in a short-term project. Facilitation of the process is crucial to create a productive transdisciplinary knowledge production process. It would support the process if donors and funding agencies with an interest in integrative research would develop their own knowledge, skills and request a plan for the transdisciplinary knowledge production process as a part of the application for funding. Additionally, funding is needed for the end-users to participate in the process. Finally, it needs to be acknowledged that integrative knowledge production is more costly and timeconsuming than disciplinary research.

\section{ACKNOWLEDGEMENTS}

This work was funded by grants from FORMAS and Mistra. Thanks to Per Angelstam that provided comments on the manuscript. My appreciation and thanks also to the participants at the IALE Landscape Ecology conference "Landscape structures, functions and management: response to global ecological change", in Brno, Czech Republic, 3-6 September 2010 for comments and discussions during the conference.

\section{REFERENCES}

Aagaard Nielsen, K., Svensson, L. (2006). Action research and interactive research: beyond practice and theory. Shaker Publishing, Maastricht.

Albrecht, G., Freeman, S., \& Higginbotham, N. (1998). Complexity and human health: the case for a transdisciplinary paradigm. Culture, Medicine and Psychiatry, 22: 55-92.

Angelstam, P., Axelsson, R., Elbakidze, M., Blicharska, M., Castro-Larrañaga, M., Mani, S. \& Törnblom, J., (unpublished $\mathrm{ms}$ ), Landscape approaches for sustainability: learning from global. European and Indian concepts.

Anonymus (2008). Ett lyft för forskning och innovation [Progress for research and innovation]. Regeringens proposition 2008/09:50, Government offices of Sweden, Stockholm.

Armitage, D., Berkes, F., \& Doubleday, N., (2007). Adaptive co-management: collaboration, learning and multi-level governance. University of British Columbia Press, Vancouver, British Columbia, Canada. 
Axelsson, R. (2009). Landscape approach for sustainable development. Doctoral dissertation, School for Forest Management, SLU. Acta Universitatis agriculturae Sueciae vol. $94 \mathrm{p}$.

Axelsson, R., Angelstam, P., \& Elbakidze, M. (2008). Landscape approaches to sustainability. In: Frostell, B., Danielsson, Å., Hagberg, L., Linnér, B.-O., Lisberg Jensen E. (Eds.) Science for sustainable development. The social challenge with emphasis on the conditions for change. 169-177 pp. VHU, Uppsala.

Bache, I., Flinders, M. (2004). Multi-level governance. Oxford university press, Oxford.

Barbour, M.T., Norton, S.B., Preston, H.R., \& Thornton, K.W. (2004). Ecological assessment of aquatic resources: linking science to decision-making. SETAC Press, Pensacola (FL) and Brussels.

Bawden, R.J. (1992). Systems approaches to agricultural development: The Hawkesbury experience. Agricultural Systems, 40: 153-176.

Blagovidov, A., Kopylova, E., Teplyakov, V. \& Shmatkov, N. (2006). Building partnerships for forest conservation and management in Russia. IUCN office for Russia and CIS, Moscow.

Borrini-Feyerabend, G., Pimbert, M., Farvar, M.T., Kothari, A., \& Renard, Y. (2004). Sharing power. Learning by doing in co-management of natural resources throughout the World. IIED and IUCN/ CEESP/ CMWG, Cenesta, Tehran.

von Bothmer, R., Schnürer, J., Åström, B., Vrede, K., \& Andersson, P. (2009). Evaluation of quality and impact at SLU (KoN 09). SLU, Uppsala.

Brozek, J., Keys, A. (1944). General aspects of interdisciplinary research in experimental biology. Science, 100: 507-512.

Brewer, G.D. (1999a). The challenges of interdisciplinarity. Policy Sciences, 32: 327-337.

Brewer, G.D. (1999b). Reflections. Policy Sciences, 32: 421-429.

Brewer, G.D., Lövgren, K. (1999). The theory and practice of interdisciplinary work. Policy Sciences, 32: 315-317.

Bryden, J., Hart, J.K. (2004). A new approach to rural development in Europe: Germany, Greece, Scotland and Sweden. The Edwin Mellen Press, Ceredigion.

Checkland, P.B. (1989). Soft systems methodology. Human Systems Management 8, 273 283.

Clark, T.W. (2002). The policy process: A practical guide for natural resource professionals. Yale University Press, New Haven, CT.

COE (2007). The European Landscape Convention. Council of Europe, Brussels.

Daniels, S.E., Walker, G.B. (2001). Working through environmental conflict- the collaborative learning approach. Praeger, Westport and London.

Dudley, N., Schlaepfer, R., Jackson, W., Jeanrenaud, J.P. \& Stolton, S. (2006). Forest quality. Assessing forests at a landscape scale. Earthscan.

EC (2007). The European Research Area: New Perspectives. COM(2007) 161, Brussels.

Elbakidze, M., Angelstam, P.K., Sandström, C., \& Axelsson, R. (2010). Multi-stakeholder collaboration in Russian and Swedish Model Forest initiatives: adaptive governance toward sustainable forest management? Ecology and Society, 15(2): 14.

Ertas, A. (2000). The academy of transdisciplinary education and research (ACTER). Journal of integrated design and process science, 4(4): 13-19. 
EUA (2009). European Universities: looking forward with confidence (Prague declaration), European University Association, Brussels.

EUA (2010). Europe's Universities beyond 2010: Diversity with a common purpose (Lisbon declaration), European University Association, Brussels.

Farley, J., Erickson, J.D., \& Daly, H.E. (2005). Ecological economics. A work-book for problem-based learning. Island Press.

Flood, R.L., Jackson, M.C. (1991). Critical systems thinking. Directed Readings, Wiley, Chichester.

Flood, R., Romm, N. (1997). From metatheory to "multimethodology". Multimethodology. The theory and practice of combining management science methodologies. John Wiley \& Sons, London.

Flood, R.L. (1999). Rethinking the fifth discipline: Learning within the unknowable. Routledge New York.

Folke, C., Hahn, T., Olsson, P., \& Norberg, J. (2005). Adaptive governance of socialecological systems. Annu. Rev. Environ. Resour. 30, 441-73.

Formas (2008). Formas Handbook 2008 for application for grants and evaluation of proposals. The Swedish Research Council for Environment, Agricultural Sciences and Spatial Planning, Stockholm.

Foss, N., Mahnke, V. (2000). Competence, governance, and entrepreneurship: advances in economic strategy research. Oxford university press, New York.

de Freitas, L., Morin, E., \& Nicolescu, B. (1994). Charter of transdisciplinarity. Adopted after the first world congress of transdisciplinarity co-organized by UNESCO National Commission in Portugal, GRT- UNESCO and the International University of Lisbon, Convento da Arrábida, Portugal, 2nd-7th of November, 1994.

Fry, E.H. (1998). The expanding role of state and local governments in US foreign policy affairs. Council on foreign relations press, New York.

Fry, G. (2001). Multifunctional landscapes: towards transdisciplinary research. Landscape and Urban Planning, 57(3-4), 159-168.

Gardner, G.T., Stern, P.C. (2002). Environmental Problems and Human Behavior. (Second Edition) Needham Heights, Allyn and Bacon.

Garfield, E. (2005). The Agony and the Ecstasy- The History and Meaning of the Journal Impact Factor. Paper presented at the international congress on peer review and biomedical publication. Chicago, September 16, 2005.

Garkovich, L. (1982). A proposal for building interdisciplinary bridges. Teaching Sociology, 9(2): 151-168.

Gibbons, M., Limoges, C., Nowotny, H., Schwartzman, S., Scott, P., \& Trow, M. (1994). The new production of knowledge: the dynamics of science and research in contemporary societies. Sage Publications, London.

Gibbons, M. (1999). Science's new social contract with society. Nature, 402 (Suppl.):8184.

Gray, B. (2008). Enhancing transdisciplinary research through collaborative leadership. Am J Prev Med, 35(2S): 124-132.

Greene, M.T. (1997). What cannot be said in science. Nature, 388: 619-620. 
Hahn, T., Olsson, P., Folke, C., \& Johansson, C. (2006). Trust-building, knowledge generation and organizational innovations: the role of a bridging organization for adaptive comanagement of a wetland landscape around Kristianstad, Sweden. Hum. Ecol. 34, 573592.

Hammer, M., Söderqvist, T. (2001). Enhancing transdisciplinary dialogue in curricula development. Ecological Economics, 38:1-5.

Harrison, O. (1997). Open space technology: User's guide. Berrett-Koehler, San Fransisco. Hirsch-Hadorn, G., Hoffman-Riem, H., Biber-Klemm, S., Grossenbacher-Mansuy, W., Joye, D., Pohl, C., Wiesmann, U. \& Zemp, E. (2008). Handbook of Transdisciplinary Research. Springer, Netherlands.

IMFN (2008). Model Forest development guide. International Model Forest Network Secretariat, Natural Resources Canada-Canadian Forest Service, Ottawa.

ISI (1994). The Thomson Reuters impact factor. Current Contents print editions, June 20, 1994, The Institute for Scientific Information.

Jakobsen, C.H., Hels, T., \& McLaughlin, W.J. (2004). Barriers and facilitators to integration among scientists in transdisciplinary landscape analyses: a cross-country comparison. Forest Policy and Economics, 6(2004): 15-31.

Johannisson, B., Gunnarsson, E. \& Stjernberg, T. (2008). Gemensamt kunskapande- den interaktiva forskningens praktik. Acta Wexionensia Nr 149/2008. Växjö University Press, Växjö.

King, A.C., Bauman, A. \& Abrams, D.B. (2002). Forging trandisciplinary bridges to meet the physical inactivity challenge in the 21st century. Am J Prev Med 23(2S): 104-106.

Kolb, D.A. (1984). Experiental learning: experiences as the source of learning and development. Prentice Hall, New Jersey.

Kvale, S. (1997). Den kvalitativa forskningsintervjun, Studentlitteratur, Lund.

Lattanzi, M. (1998). Transdisciplinarity: Stimulating synergies, integrating knowledge.

Division of philosophy and ethics, UNESCO. Retrieved 2010-03-06, from http://unesdoc.

unescoorg/images/0011/001146/114694eo.pdf

Lawrence, R.J. (2004). Housing and health: from interdisciplinary principles to transdisciplinary research and practice. Futures, 36(2004): 487-502.

Lickers, H.F., Story, P.A. (1997). Partnership building for sustainable development: A First Nation's perspective from Ontario. In: O.T. Bouman, D.G. Brand (Eds.) Sustainable forests: Global challenges and local solutions. 149-162 pp. Food Products Press, Binghampton, New York.

Madni, A.M. (2007). Transdisciplinarity: reaching beyond disciplines to find connections. Journal of Integrated Design and Process Science, 11(1): 1-11.

McGregor, S.L.T. (2004). The Nature of Transdisciplinary Research and Practice. Report, University of Halifax, Mount Saint Vincent.

MCPFE (1998). Resolution L1: People, Forests and Forestry - Enhancement of SocioEconomic Aspects of Sustainable Forest Management. Third Ministerial Conference on the Protection of Forests in Europe, 2-4 June 1998, Lisbon, Portugal.

MCPFE (2003). Resolution 3: Preserving and enhancing the social and cultural dimensions of sustainable forest management in Europe. Fourth ministerial conference on the protection of forests in Europe. 28-30 April 2003, Vienna, Austria. 
Miller, T.R., Baird, T.D., Littlefield, C.M., Kofinas, G., Chapin III, F. \& Redman, C.L. (2008). Epistemological pluralism: reorganizing interdisciplinary research. Ecology and Society 13(2): 46.

Mistra (1993). Statutes for the foundation for strategic environmental research. Mistra, Stockholm.

Mistra (2009). Mistra's operational strategy. Mistra, Stockholm.

Mayers, J., Bass, S. (2004). Policy that works for forests and people. Earthscan.

Mobjörk, M. (2004). En kluven tid en studie av idéer och föreställningar om vetenskap och kunskap i Stiftelsen för miljöstrategisk forskning, MISTRA [An Ambivalent Time: An Investigation of ideas and notions about science and knowledge in the Foundation of Strategic Environmental Research, MISTRA]. Linköping University, Linköping.

Molnar, E. (2009). The knowing-doing gap. UN 2009. United Nations report economic commission for Europe 2009. United Nations, New York and Geneva.

Morse, W., Nielsen-Pincus, M., Force, J. \& Wulfhorst, J. (2007). Bridges and barriers to developing and conducting interdisciplinary graduate-student team research. Ecology and Society, 12(2): 8 .

Myrdal, J. (2005). Om humanvetenskap och Naturvetenskap. Report 159, Department of Economics, Swedish University of Agricultural Sciences (SLU), Uppsala.

Naveh, Z. (2007). Transdisciplinary challenges in landscape ecology and restoration ecology- an anthology. Springer Landscape Series 7, Dodrecht, The Netherlands

Neuhauser, L., Richardson, D., Mackenzie, S. \& Minkler, M. (2007). Advancing transdisciplinary and translational research practice: Issues and models of doctoral education in public health. Journal of Research Practice, 3(2), Article M19.

Nicolescu, B. (2002). Manifesto of transdisciplinarity. State University of New York (SUNY) Press, New York.

Nonaka, I., Konno, N. (1998). The Concept of "Ba": Building a foundation for knowledgecreation. California Management Review, 40(3), 40-54.

Noss, R.F. (1983). A regional landscape approach to maintain diversity. BioScience, 33: 700-706.

Nowotny, H. (1999). The place of people in our knowledge. European Review 7(2), 247262.

Nowotny, H., Scott, P. \& Gibbons, M. (2001). Rethinking science: Knowledge and the public in an age of uncertainty. Polity Press and Blackwell Publishers Ltd, Cambridge and Oxford.

Olsson, P., Folke, C. \& Hahn, T. (2004). Social-ecological transformation for ecosystem management: the development of adaptive co-management of a wetland landscape in southern Sweden. Ecology and Society 9(4): 2.

Olsson, P., Folke, C., Galaz, V., Hahn, T. \& Schultz, L. (2007). Enhancing the fit through adaptive co-management: creating and maintaining bridging functions for matching scales in the Kristianstads Vattenrike Biosphere Reserve Sweden. Ecology and Society, 12(1): 28.

Pereira, A.G., Funtowicz, S. (2006). Knowledge representation and mediation for transdisciplinary frameworks: tools to inform debates, dialogues and deliberations. International Journal of Transdisciplinary Research, 1: 34-50. 
Perritt Jr, H.H. (1998). The Internet as a threat to sovereignty? Thoughts on the Internet's role in strengthening national and global governance. J. Global Legal Stud., 5: 423-442.

Peters, B.G. (2000). Governance and comparative politics. In: Pierre, J. (Ed.), Debating governance: Authority. steering, and democracy. Oxford University Press, Oxford.

Pierre, J. (2000). Introduction: Understanding governance. In: Pierre, J. (Ed.), Debating governance: Authority. steering, and democracy. Oxford University Press, Oxford.

Rauschmayer, F., Berghöfer, A., Omann, I. \& Zikos, D. (2009). Examining processes or/and outcomes? Evaluation concepts in European governance of natural resources. Env. Pol. Gov., 19: 159-173.

Rhodes, R.A.W. (1994). The hollowing out of the state. Political Quarterly, 65, 138-151.

Rhodes, R.A.W. (2003). What is new about governance and why does it matter? In: Hayward, J., Menon, A., (Eds.), Governing Europe. 61-73 pp. Oxford University Press, Oxford.

Ryen, A. (2004). Kvalitativ intervju. Liber, Malmö.

Sauer, C.O. (1925). The morphology of landscape. University of California publications in geography 2(2): 19-54, University of California.

Schön, D.A. (1983/2009). The reflective practitioner- how professionals think in action. Ashgate, Farnham.

Singer, B. (2007). How useful is the landscape approach? In: Patry, M., Ripley, S. (Eds.) World heritage forests. Leveraging conservation and the landscape level. 49-55 pp. Proceedings of the 2nd World Heritage forests meeting. March 9-11, 2005, Nancy, France. UNESCO World Heritage Centre, Paris.

Steffen, W., Sanderson, A., Tyson, P.D., Jäger, J., Matson, P.A., Moore III, B., Oldfield, F., Richardson, K., Schellnhuber, H.J., Turner, B.L. \& Wasson, R.J. (2004). Global Change and the Earth System: A Planet Under Pressure. Springer-Verlag, Berlin Heidelberg New York.

Stoker, G. (1998). Governance as theory: five propositions. Int. Soc. Sci. J., 50(155): 17-28.

Stokols, D., Fuqua, J., Gress, J., Harvey, R., Phillips, K., Baezconde-Garbanati, L., Unger J., Palmer, P., Clark, M.A., Colby, S.M., Morgan, G. \& Trochim, W. (2003). Evaluating transdisciplinary science. Nicotine \& Tobacco Research, 5 (Supplement 1): 21-39.

Stokols, D. (2006). Toward a Science of Transdisciplinary Action Research. Am J Community Psychol., 38: 63-77.

Sundström, G. (2005). Målstyrningen drar åt skogen- Om government och governance $i$ svensk skogspolitik. SCORE (Stockholms centrum för forskning om offentlig sektor), Rapportserie 2005:6, Stockholm.

Susskind, L., Cruikshank, J. (1987). Breaking the impasse: consensual approaches to resolving public disputes. Basic Books, New York.

Svensson, L., Brulin, G. \& Ellström, P.E. (2002). Interaktiv forskning -för utveckling av teori och praktik. Arbetsliv i omvandling 2002:7, Arbetslivsinstitutet, Stockholm.

Svensson, L., Nilsson, B. (2008). Partnership - as a strategy for social innovation and sustainable change. Santérus Academic Press, Stockholm.

Svensson, L., Brulin, G., Jansson, S. \& Sjöberg, K. (2009). Learning Through Ongoing Evaluation. Studentlitteratur, Lund.

Thompson Klein, J. (2004). Prospects for transdisciplinarity. Futures, 36(2004): 515-526. 
Törnblom, J. (2008). A landscape approach towards ecological integrity of catchments and streams. Doctoral dissertation, Swedish University of Agricultural Sciences, Uppsala.

Tress, B., Tress, G. \& Fry, G. (2006). Defining concepts and the process of knowledge production in integrative research. In: B., Tress, G., Tress, G., Fry, \& P., Opdam, (Eds.), Landscape research to landscape planning. 13-26 pp. Springer.

UNESCO (1996). Biosphere Reserves: The Seville strategy and the statuary framework of the world network. UNESCO, Paris.

UNESCO (2002). Biosphere reserves: special places for people and nature. UNESCO, Paris.

Vasbinder, J.W., Andersson, B., Arthur, W.B., Boasson, M., de Boer, R., Changeux, J.P., Domingo. E., Eigen. M., Fersht. A., Frenkel, D., Rees, M., Groen, T., Huber, R., Hunt, T., Holland, J., May, R., Norrby, E. \& Nijkamp, P. (2008). Transdisciplinary EU science institute needs funds urgently. Nature, 463(18): 876.

Weaver, P.M., Jordan, A. (2008). What roles are there for sustainability assessment in the policy process? J. Innovation and Sustainable Development, 3(1/2): 9-32.

Wiens, J.A., Moss, M.R., Turner, M.G. \& Mladenoff, D.J. (2007). Foundation papers in landscape ecology. Columbia University Press, New York.

Wiesmann U., Hirsch Hadorn G., Hoffmann-Riem H., Biber-Klemm S., Grossenbacher W., Joye, D., Pohl, C. \& Zemp, E. (2008). Enhancing transdisciplinary research: a synthesis in fifteen propositions. In: G., Hirsch-Hadorn, H., Hoffmann-Riem, S., Biber-Klemm, W., Grossenbacher-Mansuy, D., Joye, C., Pohl, U., Wiesmann, \& E., Zemp. Handbook of Transdisciplinary Research. 433-441 pp. Springer, Dordrecht.

Wijkman, A. (1999). Sustainable development requires integrated approaches: a world in transition. Policy Sciences, 32: 345-350. 